\title{
EARLY CHILDHOOD HUMAN CAPITAL INVESTMENT IN CHILDREN
}

Mehmet Ali SOYTAŞ ${ }^{*}$

\begin{abstract}
Early childhood investment is extremely important in forming the human capital. In order to understand the investment during this period, a human capital production function which takes parental skills, and investments as inputs and produce outcomes for children is needed. A well-known problem with the estimation of such production functions is the simultaneity of the inputs (time spent with children and income). Therefore the education production function suffers from a similar problem. However, because the output of the intergenerational education production (i.e., completed education level) is determined across generations while the inputs, such as parental time investment, are determined over the life-cycle of each generation, one can treat these inputs as predetermined and use instruments from within the system to estimate the production function. This procedure in a systems of equations framework can be estimated by a three stage least squares (3SLS) estimator. Using data on two generations from the Panel Study of Income Dynamics (PSID), this paper estimates the effect of parental characteristics and human capital investments on their children's education outcomes in a 3SLS framework.
\end{abstract}

Keywords: Time Investment, Estimation, 3SLS, PSID, Human Capital.

JEL Classification: C13, J13, J22, J62.

\section{ÇOCUKLARA ERKEN YAŞTA YAPILAN BEŞERİ SERMAYE YATIRIMLARI}

\section{Özet}

Erken yaşta çocuklara yapılan yatırımların, onların beşeri sermaye oluşumundaki etkisi çok önemlidir. $\mathrm{Bu}$ erken çocukluk dönemindeki yatırımların etkisini daha iyi anlayabilmek için, ebeveynlerin yeteneklerini ve çocuklarına yaptıkları yatırımları girdi olarak alacak ve sonuç olarak çocuklar için çıtılar üretecek bir beşeri sermaye üretim fonksiyonu gereklidir. Ancak üretim fonksiyonlarının tahmini ile ilgili en bilinen problem, girdilerin eş zamanlı olmasından kaynaklı olandır (çocuklara yapılan zaman ve parasal yatırımlar). Dolayısıyla eğitim üretim fonksiyonu da benzer bir problem ile

\footnotetext{
* Assistant Prof. Dr., Özyeğin University, Faculty of Business, Istanbul, mehmet.soytas@ozyegin.edu.tr
} 
karşı karşıyadır. Ancak nesiller arası bir eğitim üretim fonksiyonun çıktısı olan çocuğun eğitimi bir jenerasyonda ve girdiler olan ebeveyn yatırımları ve özellikleri başka bir jenerasyonda belirlendiğinden, ekonometrik yaklaşımda girdiler önceden belirlenmiş kabul edilip, tahmin edilecek denklem sistemi içerisinden değişkenler enstrüman (IV) olarak kullanılabilir. Böyle bir yaklaşımla, Üç Aşamalı En Küçük Kareler yöntemi (3SLS) ile sistem denklemleri tahmin edilebilir. Bu makale, Panel Study of Income Dynamics (PSID) verisinden iki jenerasyona ait topladığı bilgilerle, ebeveyn özelliklerinin ve zaman yatırımlarının, çocukların eğitimine olan etkisini tahmin etmektedir.

Anahtar kelimeler: : Zaman yatırımı, Tahmin, 3SLS, PSID, Beşeri Sermaye.

JEL Sınıflaması: C13, J13, J22, J62.

\section{Introduction}

When the term "human capital" was brought to the economic literature in early 1960s, it also brought a big debate about how we should see the human capabilities and treat them. The early objection was not theoretical, but more philosophical: claiming human if treated as owning inherent or gained skills which potentially are in the same category with the physical capital (that was the first impression when the term "capital" was used), we should treat human as a version of capital. This is in principle perfectly fine theoretically, whereas it opens a new avenue in our understanding which affects the way we see the human development.

Today, the term "human capital" has a well-accepted definition in economics (and possibly in many other fields) that roughly states "stock of competencies, knowledge, social and personality attributes, including creativity, cognitive abilities, embodied in the ability to perform labor so as to produce economic value" ${ }^{\text {. It }}$ role in economic development is so vital that the modern growth theory ${ }^{2}$ sees human capital as an (the) important growth factor ${ }^{3}$. Due to its important role in economics, it is not surprising that many researchers study what boosts the human capital. Obviously there are many dimensions of this question and one important dimension is that in different time periods in the life-cycle, human capital evolves differently. Take for instance, the childhood, it may be expected that the human capital increases rapider than any other period

$1 \quad$ https://en.wikipedia.org/wiki/Human_capital

2 P. M. Romer, "Human capital and growth: Theory and evidence", Carnegie-Rochester Conference Series on Public Policy, Elsevier, 32(1), 1990, pp: 251-286.

3 G. S. Becker and N. Tomes, "Human Capital and the Rise and Fall of Families", Journal of Labor Economics, 4(3), 1986, pp: 1-39. 
in our life-cycle. Cunha et $\mathrm{al}^{4}$, Cunha and Heckman ${ }^{567}$, Heckman ${ }^{8}$, Heckman et al. ${ }^{91011}$ present evidence on the importance of the early childhood on the issue of human capital, Especially the dynamics of human capital investments during the early childhood can have life-long lasting effects $^{12}$. Significant part of the variation (at least 50\%) in lifetime earnings can be explained by the attributes of individuals determined by age $18^{1314}$. Cunha et al. ${ }^{15}$ basically states that there are critical periods in the human life where the impact of investment in human capital varies. Children learn faster and in economic terms, the benefit of investment in the early childhood is far above the benefit in the following adolescence years. This is important to know since it gives the chance to direct/change the policies accordingly.

For instance it is extremely important to understand the benefits if you think about the case of government programs for the children from disadvantaged backgrounds ${ }^{16}$. From a variety of intervention studies, it is well known now that ability differences in children from different socioeconomic backgrounds can be reduced if corrective action is taken at early ages ${ }^{171819}$. One example is the Perry Preschool Program of United States which provides investment at early ages to the disadvantaged children. Cunha and Heckman ${ }^{20}$ show that there can be substantial improvements in cognitive and non-cognitive skills of the participants in the program. In turn

4 F. Cunha, J. Heckman, L. Lochner and D. Masterov, "Interpreting the Evidence on Life Cycle Skill Formation", In E. A. Hanushek, \& F. Welch (Eds.), Handbook of the Economics of Education, Chap. 12. Amsterdam: NorthHolland, 2008, pp: 697-812.

5 F. Cunha, and J. Heckman, “The Technology of Skill Formation.” American Economic Review, 97 (2), 2007, pp: 31-47.

6 F. Cunha, and J. Heckman, "Formulating, Identifying and Estimating the Technology of Cognitive and Noncognitive Skill Formation”, Journal of Human Resources, 43(4), 2008, pp: 738-782.

7 F. Cunha, and J. Heckman, “The Economics and Psychology of Inequality and Human Development”, Journal of the European Economic Association, 7(2-3), 2009, pp: 320-364.

8 J. Heckman, “Schools, Skills and Synapses”, Economic Inquiry, 46(3), 2008, pp: 289-324.

9 J. Heckman et al., "Analyzing Social Experiments as Implemented: A Reexamination of the Evidence From the HighScope Perry Preschool Program”, Quantitative Economics, 1(1), 2010, pp: 1-46.

10 J. Heckman et al., “The rate of return to the HighScope Perry Preschool Program”, Journal of Public Economics, 94, 2010, pp: 114-128.

11 J. Heckman et al., "Understanding the Mechanisms through Which an Influential Early Childhood Program Boosted Adult Outcomes", American Economic Review, 103(6), 2013, pp: 2052-86.

12 P. Carneiro et al., "Labor Market Discrimination and Racial Differences in Premarket Factors", Journal of Law and Economics, 48(1), 2005.

13 M. Huggett, G. Ventura, and A. Yaron, “Sources of Lifetime Inequality”, American Economic Review, 101(7), 2011, pp: 2923-54.

14 M. Keane, K. I. Wolpin, “The Career Decisions of Young Men”, Journal of Political Economy, 105(3), 1997, pp: 473522.

15 F. Cunha et al., Ibid.

16 Measuring benefits are usually not easy with any social program that requires government spending. Costs are also important, however they are obviously easier to measure.

17 F. Cunha et al., Ibid.

18 F. Cunha, and J. Heckman, Ibid.

19 J. Heckman et al., Ibid.

20 F. Cunha, and J. Heckman, Ibid. 
those skills are what matters in many different aspects of life; like having better education, successful marriages, low probability of committing crime, better labor market outcomes, etc.

Moreover, Cunha and Heckman ${ }^{21}$ conduct a simulation study to address the cost of investments in different periods of the children's life. Consider three different policies. The first one is like the Perry Preschool program mentioned above which provides funds at early stages that moves children from the lower end of the skill distribution to a higher level. This gain can be achieved by moving parental investment from the bottom decile (1/10 of the population) to around seventh decile of the family investment distribution. Suppose in this policy, there is no follow-up investment. They also consider another policy for the same target population that postpones the investment until adolescence. It is designed to compensate early shortfalls by investing larger amounts in the adolescence years to achieve the same high-school graduation rates observed in the Perry program. Real life examples of this policy are college tuition programs, adolescence literacy programs, and mentoring programs. The simulation exercise in Cunha and Heckman ${ }^{22}$, and other supporting evidence in Heckman ${ }^{23}$, Heckman et al. ${ }^{24}$ show that the cost of investment in the adolescence targeted program is more than 35 percent larger than in the Perry Preschool program. Late remediation is possible, but it is costly.

Early childhood investment is extremely important but follow-up investments should complement it. Such a policy will produce the best outcome for the children. However when it comes to design a government policy to promote the children from disadvantaged backgrounds, the resources available for investment are not that flexible most of the time and generally investments are targeted to for certain periods. The current research on human capital tells us a better way to increase the life outcomes of those children through a continuous investment starting from childhood. Of course, there remain many other interesting questions unanswered such as what the content of the family investment should be. Are we referring to monetary investments like buying books, toys, sending the child to a chess class, or parental time spent with the kids are of equal importance? This is an active research topic which is addressed in Bernal2 ${ }^{25}$, Del Boca et al. ${ }^{26}$, Guryan ${ }^{27}$, Lee and Seshadri ${ }^{28}$, Heckman and Mosso ${ }^{29}$ among others. In this respect, this

21 F. Cunha, and J. Heckman, Ibid.

22 F. Cunha, and J. Heckman, Ibid.

23 J. Heckman, Ibid.

24 J. Heckman et al., Ibid.

25 R. Bernal, “The Effect of Maternal Employment and Child Care on Children's Cognitive Development", International Economic Review, 49 (4), 2008, pp: 1173-1209.

26 D. Del Boca et al., "Household choices and child development", The Review of Economic Studies, 81(1), 2014, pp: 137-185.

27 J. Guryan et al., "Parental Education and Parental Time with Children", Journal of Economic Perspectives, 22(3), 2008, pp: 23-46.

28 S-Y. Lee, and A. Seshadri, "On the intergenerational transmission of economic status", Unpublished manuscript, University of Wisconsin-Madison, Department of Economics. 2014.

29 J. Heckman and S. Mosso, "The Economics of Human Development and Social Mobility", Annual Review of Economics, 6, 2014, pp: 689-733. 
paper analyzes the relationship between parents' monetary and time investments that they spent on their children to increase children's human capital in the early childhood and the children's adult outcomes. Panel Study of Income Dynamics is used to conduct the empirical analysis. The results show that potentially both money and time are important investment channels to achieve human capital transfers from parents to children. The parental characteristics also matters. More educated parents enjoy higher outcomes with the same level of investment. This can be explained by genetically transfer of traits (such as abilities), or might mean more investigation is needed to understand the environmental factors during the childhood. One such factor studied in Gayle et al. ${ }^{3031}$ is the family. In U.S, the composition of families is changing, and the share of stable families is becoming less over time. This among other things may affect the intensity of the human capital investment.

The paper is organized as follows. Section 2 describes the data and the variables used in the analysis. Section 3 presents the econometric model and the results. Section 4 discusses the main findings in a general economic context and highlights the importance of time investment in children. Section 5 concludes.

\section{Data}

I use data from Family-Individual File of Panel Study of Income Dynamics (PSID) trough waves from 1968 to 1997. Individuals are selected by setting the individual level variables "Relationship to Head" to head, or wife, or son, or daughter. All sons or daughters are dropped if they are younger than 17 years of age. This initial selection produces a sample of 12,051 and 17,744 males and females, respectively; these individuals were observed for at least one year during our sample period. Our main sample contains 423,631 individual-year observations.

Only white and black individuals between the ages of 17 and 55 are kept in the sample. The econometric estimation equation requires the knowledge of the five years of participation decisions in the labor market. This immediately eliminates individuals with fewer than five years of sequential observations. This reduces the number of individual-year observations to 139,827 . To track parental time input throughout a child's early life, I dropped parents observed only after their children are older than 16 years of age. I also dropped parents with missing observations during the first 16 years of their children's lives. Furthermore, if there are missing observations on the spouse of a married individual, then that individual is dropped from our sample.

30 G-L. Gayle et al., "What Accounts for the Racial Gap in Time Allocation and Intergenerational Transmission of Human Capital?", Unpublished Manuscript, Washington University in St. Louis, Department of Economics, 2014a.

31 G-L. Gayle et al., "Family Structure and Intergenerational Income Mobility”, Unpublished Manuscript, Washington University in St. Louis, Department of Economics, 2014 b. 
Table I. Main Data Summary Statistics

\begin{tabular}{|c|c|c|c|c|c|c|}
\hline \multirow[b]{2}{*}{ Variable } & \multicolumn{2}{|c|}{$\begin{array}{c}(1) \\
\text { Full Sample } \\
\end{array}$} & \multicolumn{2}{|c|}{$\begin{array}{c}\text { (2) } \\
\text { Parents' Sample } \\
\end{array}$} & \multicolumn{2}{|c|}{$\begin{array}{c}\text { (3) } \\
\text { Children's S ample } \\
\end{array}$} \\
\hline & $\mathrm{N}$ & Mean & $\mathrm{N}$ & Mean & $\mathrm{N}$ & Mean \\
\hline Female & 115,280 & 0.545 & 86,302 & 0.552 & 28,978 & 0.522 \\
\hline Black & 115,280 & 0.223 & 86,302 & 0.202 & 28,978 & 0.286 \\
\hline Married & 115,280 & 0.381 & 86,302 & 0.465 & 28,978 & 0.131 \\
\hline Age & 115,280 & $\begin{array}{c}26.16 \\
(7.699)\end{array}$ & 86,302 & $\begin{array}{l}27.968 \\
(7.872)\end{array}$ & 28,978 & $\begin{array}{l}20.756 \\
(3.511)\end{array}$ \\
\hline Education & 115,280 & $\begin{array}{l}13.438 \\
(2.103)\end{array}$ & 86,302 & $\begin{array}{l}13.516 \\
(2.138)\end{array}$ & 28,978 & $\begin{array}{l}13.209 \\
(1.981)\end{array}$ \\
\hline Number of children & 115,280 & $\begin{array}{c}0.616 \\
(0.961)\end{array}$ & 86,302 & $\begin{array}{l}-0.766 \\
(1.028)\end{array}$ & 28,978 & $\begin{array}{c}0.167 \\
(0.507)\end{array}$ \\
\hline Annual labor income & 114,871 & $\begin{array}{l}16,115 \\
(24622)\end{array}$ & 86,137 & $\begin{array}{r}19,552 \\
(26273)\end{array}$ & 28,734 & $\begin{array}{c}5,811 \\
(14591)\end{array}$ \\
\hline Annual labor market hours & 114,899 & $\begin{array}{c}915 \\
(1041)\end{array}$ & 86,185 & $\begin{array}{c}1078 \\
(1051)\end{array}$ & 28,714 & $\begin{array}{c}424 \\
(841)\end{array}$ \\
\hline Annual housework hours & 66,573 & $\begin{array}{c}714 \\
(578)\end{array}$ & 58,564 & $\begin{array}{c}724 \\
(585)\end{array}$ & 8,009 & $\begin{array}{c}641 \\
(524)\end{array}$ \\
\hline Annual time spent on children & 115,249 & $\begin{array}{c}191 \\
(432)\end{array}$ & 86,275 & $\begin{array}{c}234 \\
(468)\end{array}$ & 28,974 & $\begin{array}{l}63.584 \\
(259)\end{array}$ \\
\hline Number of individuals & 12,318 & & 6,813 & & 5,505 & \\
\hline
\end{tabular}

Note: Standard deviations are listed in parentheses. Source: Data from the Family-Individual File of the PSID; including individuals surveyed between 1968 and 1997. Yearly earnings are measured in 2005 dollars. Education measures the years of completed education. There are fewer observations for annual housework hours than time spent with children because single individuals with no child are coded as missing for housework hours but by definition are set to zero for time spent with children.

Table 1 presents the summary statistics for our sample; column (1) summarizes the full sample, column (2) focuses on the parents, and column (3) summarizes the characteristics of the children. It shows that the first generation is on average 7 years older than the second generation in our sample. As a consequence, a higher proportion is married in the first generation relative to the second generation. The male-to-female ratio is similar across generations (about 55 percent female). However, the sample contains a higher proportion of blacks in the second generation that in the first generation (about 29 percent in the second and 20 percent in the first generation). This higher proportion of blacks in the second generation is due to the higher fertility rate among blacks in the sample. There are no significant differences across generations in the years of completed education. As would be expected, because on average the second generation in the sample is younger than the first generation, the first generation has a higher number of children, annual labor income, labor market hours, housework hours, and time spent with children. The 
second-generation sample does span the same age range, 17 to 55, as the first sample. This final sample is further constrained to obtain the parents who are matched with their children when they are adults. The unique structure of PSID allows the researcher to match the parents to their children which is essential for the analysis in this paper. In the econometric estimation, only the parents and child pairs with no missing observations in the first five years of the child life are included. This brings the sample to 1335 matched parents-child observations.

\section{I. Parental time with young children}

The PSID measures annual hours of housework for each individual; however, it does not provide data on time parents spend on child care. This variable is estimated using a variation of the approach used in the literature ${ }^{3233}$. Hours with children are computed as the deviation of housework hours in a particular year from the average housework hours of individuals with no child by gender, education, and year ${ }^{3435}$. Negative values are set to zero and child care hours are also set to zero for individuals with no children. In addition, in the estimation, I do not use levels of hours measure; instead I use a discrete measure with three levels of time spent with children for men and women, which reduces the problem. Furthermore, although this measure may not capture directly activities with children, I find, nevertheless, that it has a strong predictive power on educational outcomes (above and beyond other socioeconomic and demographic variables). In addition, previous studies also found that this variable predicts educational outcomes.

To ensure that the parental time variable captures the variation of time spent with children by race and to further assess the robustness of the variable, I benchmark the pattern of the measure of parental time with young children from the PSID against data from the American Time Use Survey (ATUS). The ATUS contains cross-sectional data on how Americans spend their time, including measures for different household activities such as child care. Figure 2.1 summarizes the parental time with young patterns by race and marital status for both the PSID and the ATUS data. The top panel of Figure 2.1 presents the time mothers spend with their children younger than six (henceforth referred to as young children) by race and the number of young children. It shows that the normalized parental time computed in the PSID tracks the actual time spent with young children reported in the ATUS time diaries. Furthermore, for any number of young children, white mothers spend more time with children than black mothers. The middle panel of Figure 2.1 presents maternal time with young children by marital status. As is well documented in the economics and sociology literature, single parenthood affects child outcomes. For instance

32 C. R. Hill and F. P. Stafford, "Allocation of time to preschool children and educational opportunity", Journal of Human Resources, 9(3), 1974, pp: 323-341.

33 C. R. Hill and F. P. Stafford, "Parental Care of Children: Time Diary Estimates of Quantity, Predictability, and Variety”, Journal of Human Resources, 15(2), 1980, pp: 219-239.

34 A. Leibowitz, "Parental inputs and children's achievement", Journal of Human Resources, 12(2), 1977, pp: $242-251$.

35 L. Datcher-Loury, "Effects of mother's home time on children's schooling”, The Review of Economics and Statistics, 70(3), 1988, pp: 367-373. 
Couch and Lillard ${ }^{36}$, Burtless ${ }^{37}$, Bjorklund and Chadwick ${ }^{38}$, Ellwood and Jencks ${ }^{39}$, Martin ${ }^{4041}$, McLanahan and Percheski ${ }^{42}$ and Bloome ${ }^{43}$ present evidence among others. Single mothers spend less time with children than married mothers, and black mothers are about five times more likely to be single mothers ${ }^{44}$. It is tempting to conclude that the racial difference in maternal time is explained completely by the different composition of single mothers in the different racial groups.

The bottom panel of Figure 1 presents maternal time with young children by race and marital status. There is no discernible difference in time spent with young children between black and white single mothers. According to the PSID, white single mothers spend slightly more time than black single mothers, but the pattern is reversed in the ATUS data. However, black married mothers spend an average 180 hours per year less than white married mothers. This shows that the racial gap in time spent with their young children is due not only to the compositional effect of single mothers, but also to the significant differences in the maternal time with young children between black and white married households.

36 K. A. Couch and D. R. Lillard, "Divorce, Educational Attainment, and the Earnings Mobility of Sons", Journal of Family and Economic Issues, 18(3), 1997, pp: 231-245.

37 G. Burtless, "Effects of Growing Wage Disparities and Changing Family Composition on the US Income Distribution", European Economic Review, 43(4), 1999, pp: 853-865.

38 A. Björklund and L. Chadwick, "Intergenerational Income Mobility in Permanent and Separated Families", Economics Letters, 80(2), 2003, pp: 239-246.

39 D. T. Ellwood and C. Jencks, "The uneven spread of single-parent families: What do we know? Where do we look for answers?", Social inequality, 1, 2004, pp: 3-77.

40 M. A. Martin, "Family Structure and Income Inequality in Families with Children, 1976 to 2000", Demography, 43(3), 2006, pp: 421-445.

41 M. A. Martin, "Family Structure and The Intergenerational Transmission of Educational Advantage", Social Science Research, 41(1), 2012, pp: 33-47.

42 S. McLanahan, and C. Percheski, "Family Structure and the Reproduction of Inequalities", Annual. Review of Sociololgy, 34, 2008, pp: 257-276.

43 D. Bloome, "Family Structure, Race and Intergenerational Income Mobility in the United States", Unpublished manuscript, University of Michigan, 2014.

44 See Table 2. In the PSID 69\% of black children under the age of six have a single mother, compared to $13 \%$ of white children younger than six who have a single mother. 

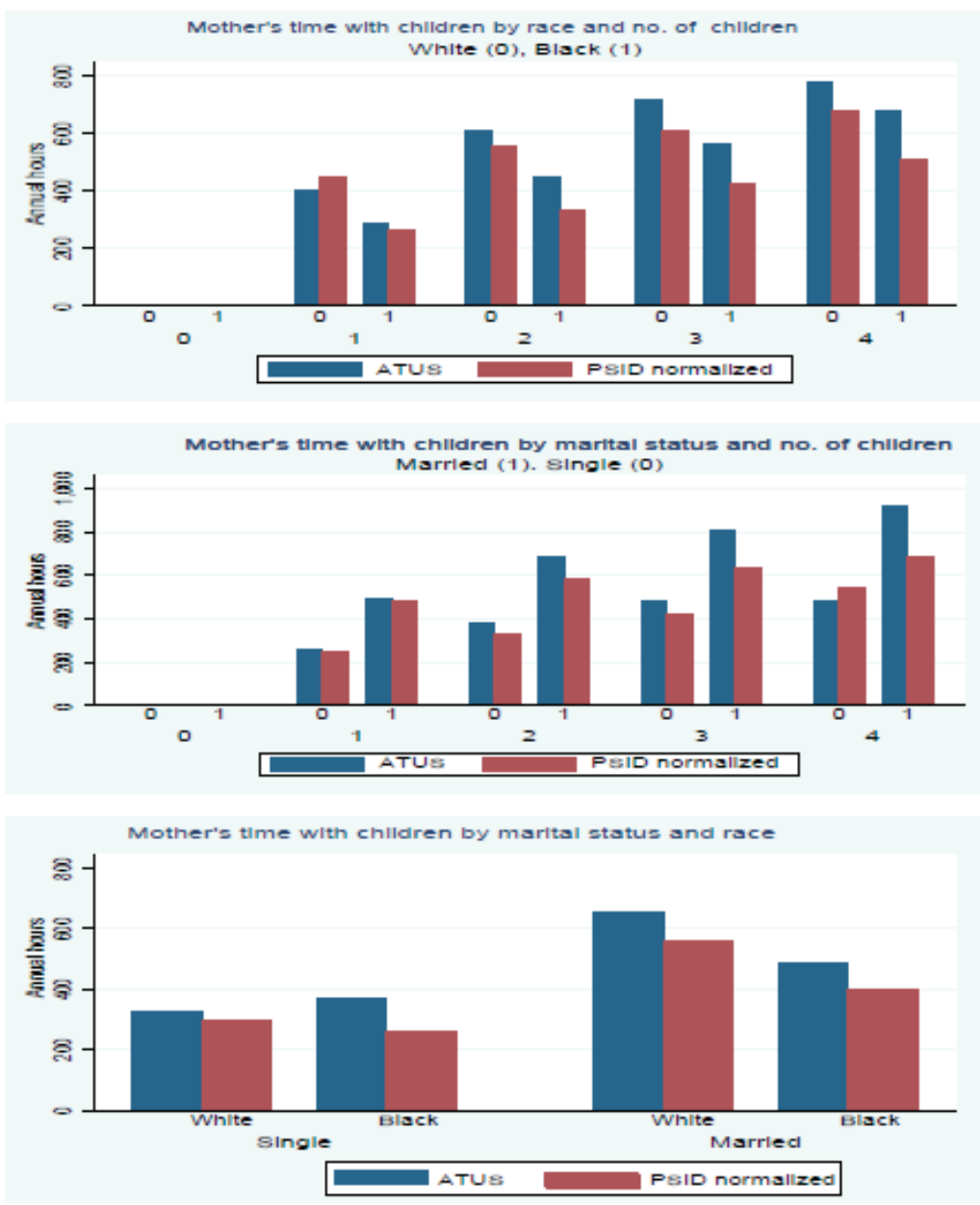

Figure I. Parental Time with Young Children

Source: G-L. Gayle et al., "What Accounts for the Racial Gap in Time Allocation and Intergenerational Transmission of Human Capital?", 2014.

Table 2 presents characteristics of the sample by gender, race, and marital status. The first three rows present the annual time spent with young children, number of children and annual housework hours. It shows that married black males spend slightly more time with young children than white married males; this is also true for housework in general. While single black males spend more time on housework than single white males, they spend significantly less time with young children; this is entirely due to the low number of single black males reporting that they are fathers in the PSID. Overall, the number of hours spent with young children by single males is very small. 
Table 2. Summary Statistics by Race, Gender, and Marital Status

\begin{tabular}{lcccccccc}
\hline & \multicolumn{2}{c}{ Single } & \multicolumn{2}{c}{ Married } & \multicolumn{2}{c}{ Single } & \multicolumn{2}{c}{ Married } \\
\hline \hline Variable & White & Black & White & Black & White & Black & White & Black \\
Annual time & 17.4 & 3.3 & 86 & 99.1 & 82.9 & 136.7 & 331 & 250.3 \\
with children & $(119)$ & $(48)$ & $(210)$ & $(250)$ & $(271)$ & $(323)$ & $(484)$ & $(407)$ \\
\# of children & 0.19 & 0.07 & 1.22 & 1.21 & 0.57 & 1.14 & 1.27 & 1.43 \\
& $(0.55)$ & $(0.35)$ & $(0.96)$ & $(1.08)$ & $(0.9)$ & $(1.05)$ & $(1.01)$ & $(1.07)$ \\
Housework & 379 & 455 & 362 & 376 & 596 & 732 & 1057 & 972 \\
& $(330)$ & $(408)$ & $(324)$ & $(370)$ & $(485)$ & $(538)$ & $(601)$ & $(560)$ \\
Age & 27.3 & 27.3 & 33.1 & 33 & 29.1 & 29.3 & 30.2 & 29.8 \\
& $(6.29)$ & $(5.88)$ & $(6.8)$ & $(6.62)$ & $(7.62)$ & $(6.8)$ & $(6.88)$ & $(6.56)$ \\
Education & 13.9 & 12.6 & 14 & 12.9 & 14 & 13 & 13.7 & 13.3 \\
& $(2.09)$ & $(1.79)$ & $(2.16)$ & $(1.99)$ & $(2.13)$ & $(1.74)$ & $(2.06)$ & $(1.88)$ \\
Labor income & 35,104 & 20,062 & 51,072 & 35,824 & 26,179 & 16,447 & 19,364 & 18,180 \\
& $(25611)$ & $(17371)$ & $(34197)$ & $(22222)$ & $(20500)$ & $(15945)$ & $(20522)$ & $(16447)$ \\
Wage rate & 17.3 & 11.2 & 23.9 & 17.8 & 14.4 & 10 & 12.8 & 11.1 \\
& $(12.4)$ & $(9.42)$ & $(17.8)$ & $(12)$ & $(11)$ & $(10)$ & $(13.2)$ & $(10.2)$ \\
Annual & 1,981 & 1,559 & 2,186 & 1,996 & 1,672 & 1,304 & 1,209 & 1,332 \\
work hours & $(740)$ & $(917)$ & $(624)$ & $(695)$ & $(796)$ & $(909)$ & $(891)$ & $(856)$ \\
\# of observations & 4,792 & 2,987 & 13,257 & 2,908 & 7,278 & 6,926 & 20,074 & 6,131 \\
\hline \hline
\end{tabular}

Note: Standard deviations are listed in parentheses. Source: Data from the Family-Individual File of the PSID, including individuals surveyed between 1968 and 1997. Yearly earnings are measured in 2005 dollars. Education measures the years of completed education. There are fewer observations for annual housework hours than time spent with children because single individuals with no child are coded as missing for housework hours but by definition are set to zero for time spent with children.

Single black females spend about 70 percent more time with children than single white females, but this is because single black females have, on average, twice as many children as single white females. Married black females on average have slightly more children than married white females (1.43 for blacks versus 1.27 for whites) but spend 30 percent less time with young children than married white females. Black married females spend less time on housework than white married females. It is also noteworthy that despite the absence of a racial gap in age, there is a 1-year racial gap in completed education between whites and blacks for all groups except married females. Thus in terms of demographic characteristics, black and white married females are similar but black married females spending less time with young children.

\subsection{Education outcomes of children}

Figure 2 presents the education distribution by race and gender. Clearly there is a large gender and race gap in outcomes. Blacks have worse outcomes than whites, and girls have better outcomes than boys. Comparing those with a high school education or less and those with at least some college degree, the gender gap is larger than the race gap. That is, the gender gap in the probability of achieving only a high school diploma or less is higher for boys and girls than it is for blacks 
and whites. However, in comparison, for those with college degree or more, the race gap is larger than the gender gap; whites have rates about twice as high as those of blacks. Of course, these educational gaps translate into earnings gaps as well ${ }^{45}$.

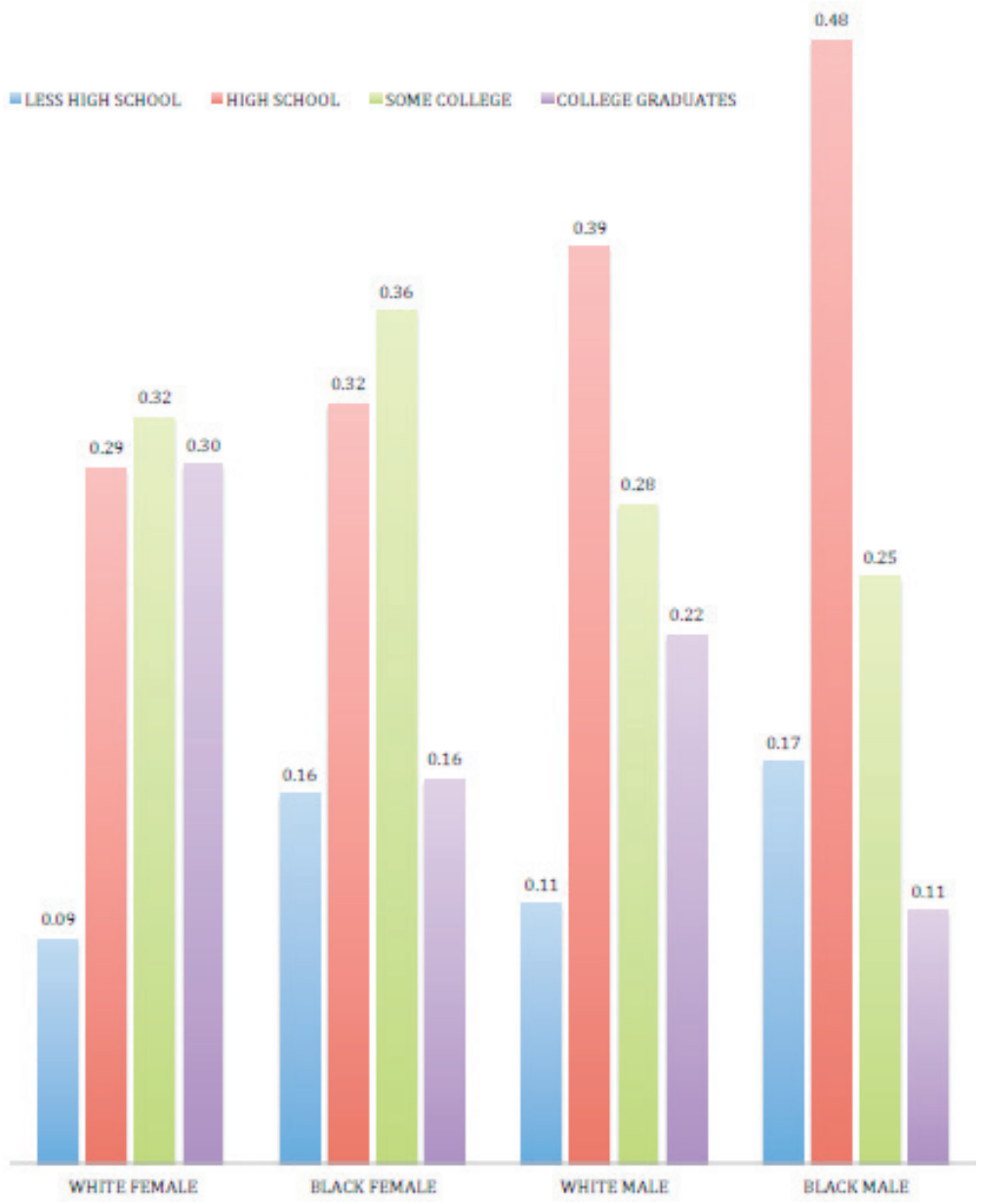

Figure 2. Distribution of Educational Outcomes of Children

\section{Econometric Model and Estimation}

Using data on two generations from the PSID, I estimate the effect of parental characteristics and human capital investments on their children's' education outcomes. The preliminary evidence from the data shows that there exists significant variation in both parental inputs and also

45 G. S. Becker, "A Treatise on the Family." Harvard University Press. 1981. 
children's outputs. This is very apparent for instance in the large black-white achievement gap. However estimating the effect of time investment, we need to have a human capital production function which takes parental skills and investments as inputs and produce outcomes for children. A well-known problem with the estimation of production functions is the simultaneity of the inputs (time spent with children and income in this paper). Therefore the education production function suffers from a similar problem. However, because the output of the intergenerational education production (i.e., completed education level) is determined across generations while the inputs, such as parental time investment, are determined over the life-cycle of each generation, we can treat these inputs as predetermined and use instruments from within the system to estimate the production function. This procedure in a systems of equations framework can be estimated by a three stage least squares estimator.

Table 3 presents results of a Three Stage Least Squares estimation of the system of individual educational outcomes; the estimates for the other endogenous variables are given in Table A.1 in the appendix. The system includes the linear probabilities of the education outcomes equation as well as the labor supply, income, and time spent with children equations. The estimation uses the mother's and father's labor market hours over the first 5 years of the child's life as well as linear and quadratic terms of the mother's and father's age on the child's fifth birthday as instruments. The estimation results show that controlling for all inputs, a child whose mother has a college education has a higher probability of obtaining at least some college education and a significantly lower probability of not graduating from high school relative to a child with a less-educated mother; while the probability of graduating from college is also larger, it is not statistically significant. If a child's father, however, has some college or college education the child has a higher probability of graduating from college. This is consistent with the findings of RiosRull and Sanchez-Marcos ${ }^{46}$.

We measure parental time investment as the sum of the parental time investment over the first 5 years of the child's life. The total time investment is a variable that ranges between 0 and 10 since low parental investment is coded as 1 and high parental investment is code as 2 . The results in Table 3 show that while a mothers' time investment significantly increases the probability of a child graduating from college or having some college education, a father's time investment significantly increases the probability of the child graduating from high school or having some college education. These estimates suggest that while a mother's time investment increases the probability of a high educational outcome, a father's time investment truncates low educational outcome. However, time investment of both parents is productive in terms of their children's education outcomes. It is important to note that mothers' and fathers' hours spent with children are at different margins, with mothers providing significantly more hours than fathers. Thus, the magnitudes of the discrete levels of time investment of mothers and fathers are not directly comparable since what constitutes low and high investment differs across genders.

46 J-V. Rios-Rull and V. Sanchez-Marcos, “College Attainment of Women”, Review of Economic Dynamics, 5(4), 2002, pp: 965-998. 
Table 3. Three-stage Least Squares Estimation: Child Education Outcomes

\begin{tabular}{lccc}
\hline & High & Some & College \\
Variable & School & College & \\
\hline \hline High school father & 0.063 & 0.003 & -0.002 \\
& $(0.032)$ & $(0.052)$ & $(0.044)$ \\
Some college father & 0.055 & 0.132 & 0.055 \\
& $(0.023)$ & $(0.038)$ & $(0.031)$ \\
College father & -0.044 & 0.008 & 0.120 \\
& $(0.032)$ & $(0.051)$ & $(0.042)$ \\
High school mother & 0.089 & 0.081 & -0.019 \\
& $(0.040)$ & $(0.065)$ & $(0.052)$ \\
Some college mother & 0.007 & -0.041 & 0.017 \\
& $(0.030)$ & $(0.049)$ & $(0.039)$ \\
College mother & 0.083 & 0.120 & 0.040 \\
Mother's time & $(0.036)$ & $(0.057)$ & $(0.047)$ \\
Father's time & -0.014 & 0.080 & 0.069 \\
& $(0.021)$ & $(0.034)$ & $(0.027)$ \\
Mother's labor income & 0.031 & 0.100 & 0.026 \\
Father's labor income & $(0.019)$ & $(0.029)$ & $(0.025)$ \\
Female & -0.025 & -0.013 & 0.005 \\
& $(0.009)$ & $(0.014)$ & $(0.011)$ \\
Black & 0.001 & 0.001 & 0.002 \\
Number of siblings younger than age 3 & $(0.003)$ & $(0.004)$ & $(0.003)$ \\
Number of siblings between ages 3 and 6 & -0.002 & 0.135 & 0.085 \\
& $(0.017)$ & $(0.028)$ & $(0.022)$ \\
& 0.020 & 0.082 & 0.043 \\
& $(0.039)$ & $(0.063)$ & $(0.051)$ \\
& -0.014 & -0.107 & -0.043 \\
& $(0.017)$ & $(0.027)$ & $(0.022)$ \\
& -0.029 & -0.047 & -0.012 \\
& $(0.019)$ & $(0.030)$ & $(0.025)$ \\
& 0.855 & -0.231 & -0.359 \\
& $(0.108)$ & $(0.172)]$ & $(0.140)$ \\
& 1335 & 1335 & 1335 \\
\hline
\end{tabular}

In Table 3, the standard errors are listed in parenthesis. The excluded class is less than high school in the estimation. Mother's (father's) labor income is the total labor income of the father (mother) in the first 5 years of the child's life. Mother's (father's) time is total time investment of the father (mother) in the first 5 years of the child's life (sum of discrete variable which takes $0,1,2$ values). Instruments used in the 3SLS estimation are mother's and father's labor market hours over the child's first 6 years of life, linear and quadratic terms of mother's and father's age when the child was 5 years old. The results in Table 3 also show that females are more likely to have some college education or to graduate from college than males. We find there are no 
significant differences between black and white children's outcomes once we control for the inputs, parental characteristics, and number of siblings. We did not find evidence for increasing returns to scale with respect to the number of children at the household; siblings younger than three have a negative effect on outcomes, but siblings between the ages of three and six do not have a significant effect.

Table 4 presents the predicted probabilities of a child's education outcome by parental education and time investment for a white male child as an example. This exercise illustrates the quantitative magnitude of the effect of parental time investment on education outcomes. With no time investment, the probability the child will obtain more than a high school education is roughly nonexistent regardless of the parents' education. The probability of graduating from college rises at an increasing rate with time investment. If both parents have less than a high school education and invest no parental time over the child's first 5 years of life, the child has a $20.2 \%$ chance of not completing high school and a 79.8\% chance of graduating from high school. However, if both parents invest the average time observed in our sample the chance of not completing high school drops to $11.5 \%$, the probability of some college increases to $49.2 \%$, and the chance of graduating from college increases to $15.9 \%$. If both parents invest intense ${ }^{47}$ amount of time to their children, then the probabilities of not graduating from high school or only graduating from high school are zero, the probability of some college is $36.8 \%$, and the probability of graduating from college is $63.2 \%$. This pattern is repeated for other parental education groups; if both parents are college graduates but do not invest then the child has no chance of graduating from college. If both parents make average time investment, the probability rises to $43.2 \%$, and if they invest the maximum amount of time it is $90.6 \%$. These results suggest there are significant returns to parental time investment and quantitatively the effect of time investment still matters a lot even the monetary investments are controlled for. This finding is particularly important and in-line with Del Boca et al ${ }^{48}$.

\section{Discussion}

The results present a considerable gap in education outcome between blacks and whites. Using the estimates in Table 3.1, whites are two times more likely to graduate from college and 1.7 times less likely to not have a high school diploma. I estimate the effect of parental characteristics (such as education and skill level, as well as income and time input in the first 6 years) on the education outcomes of children; I find that time spent with children has a significant and large effect on education outcome. Therefore, it is an important factor in explaining the gap in education outcomes of black and white children. That is, although there is significant persistence in educational status across generations, the time spent with children by both parents significantly predicts the education outcome of children. While I find that both mothers' and fathers' time is

47 Setting the time investment to the highest possible amount.

48 D. Del Boca et al., Ibid. 
important, mothers' time increases the probability of children graduating from college or having some college education, while fathers' time reduces the probability of not graduating from high school.

Table 4. Predicted probability of a white male child's education outcome

\section{CHILD'S EDUCATION (\%)}

\begin{tabular}{llccccc} 
& Mother's Education & Time Investr & $\begin{array}{c}\text { Less than } \\
\text { High } \\
\text { School }\end{array}$ & $\begin{array}{c}\text { High } \\
\text { School }\end{array}$ & $\begin{array}{c}\text { Two year } \\
\text { college }\end{array}$ & $\begin{array}{c}\text { College } \\
\text { graduate }\end{array}$ \\
\hline \hline Less than high school & Less than high school & 0 & 20.2 & 79.8 & 0.0 & 0.0 \\
High school & High school & 0 & 8.7 & 91.3 & 0.0 & 0.0 \\
Two year college & Two year college & 0 & 5.0 & 95.0 & 0.0 & 0.0 \\
College graduate & College graduate & 0 & 6.5 & 93.5 & 0.4 & 0.0 \\
& & & & & & \\
Less than high school & Less than high school & Average & 11.5 & 23.5 & 49.2 & 15.9 \\
High school & High school & Average & 0.0 & 28.2 & 56.2 & 15.6 \\
Two year college & Two year college & Average & 0.0 & 20.2 & 55.6 & 24.2 \\
College graduate & College graduate & Average & 0.0 & 9.6 & 47.2 & 43.2 \\
& & & & & & \\
Less than high school & Less than high school & Intense & 0.0 & 0.0 & 36.8 & 63.2 \\
High school & High school & Intense & 0.0 & 0.0 & 37.1 & 62.9 \\
Two year college & Two year college & Intense & 0.0 & 0.0 & 28.4 & 71.6 \\
College graduate & College graduate & Intense & 0.0 & 0.0 & 9.4 & 90.6 \\
\hline \hline
\end{tabular}

There is an extensive literature on the relative importance of pre-market skill on racial gaps and labor market discrimination in determining the observed racial gaps in labor market outcomes ${ }^{49}$. Heckman and Mosso $^{50}$ is a comprehensive recent survey of this literature. Cameron and Heckman ${ }^{51}$ 's findings are closely related to my findings in terms of the interpretation. They investigate the sources of racial disparity in college attainment and concluded that the long-term socioeconomic factors are what determine the disparity as opposed to short term credit constraints. I find that family income in the first 5 years did not directly affect children's educational attainment after controlling for parental education, skill, siblings, and time spent with children. Therefore the government programs aiming to improve outcomes for disadvantaged children from poor neighborhoods should be careful in the types of transfers they make. In this paper, also in Del

49 R. Fryer, "Racial inequality in the 21st century: The declining significance of discrimination", in Handbook of Labor Economics, Vol. 4, 2011, pp: 855-971.

50 J. Heckman and S. Mosso, Ibid.

51 S. V. Cameron, and J. Heckman, “The Dynamics of Educational Attainment for Black, Hispanic, and White Males”, Journal of Political Economy, 109(3), 2001, pp: 455-499. 
Boca et al..$^{52}$, it is shown that monetary inputs are less productive in increasing child outcomes. This fact combined with the success of Perry Preschool Program type comprehensive investment schedules including the time investment, tell us the early childhood cognitive development requires time investment as a separate source of input. This makes the problem more complex than we might assume. Since unlike the other educational tools and educational materials that can be bought from the market, and also unlike the physical childcare time, there might not be a quite good substitute for the parental investment time in the market.

\section{Conclusion}

This paper estimates a human capital production technology using the parental monetary and time inputs during the early childhood as investments. I find that accounting for the endogeneity in the parental labor supply, income, and time spent with children decisions is important for understanding the mechanism of intergenerational transmission of human capital. A system of equations is formed using the endogenous variables and other exogenous sources of variations. The system includes the linear probabilities of the education outcomes equation as well as the labor supply, income, and time spent with children equations. The estimation uses the mother's and father's labor market hours over the first 5 years of the child's life as well as linear and quadratic terms of the mother's and father's age on the child's fifth birthday as instruments. The estimation results show that controlling for all inputs, a child whose mother has a college education has a higher probability of obtaining at least some college education and a significantly lower probability of not graduating from high school relative to a child with a less-educated mother; while the probability of graduating from college is also larger, it is not statistically significant. If a child's father, however, has some college or college education the child has a higher probability of graduating from college.

Parental time with children in the first 5 years is an important mechanism of transmission of human capital whereas family income in the first 5 years does not directly affect children's educational attainment after controlling for parental education, skill, siblings, and time spent with children. This finding has important policy implications. Public policies towards children from disadvantaged backgrounds should not only focus on direct/indirect monetary transfers, but a successful policy should find a remedy to address the other important input; time investment of parents. This in general might not be an easy task, and will depend on the substitutability of the

parental time. Future studies should investigate more on the dynamics of time investment and future outcomes for children. 


\section{References}

BECKER, G. S., “A Treatise on the Family”, Harvard University Press, 1981.

BECKER, G. S., and Tomes, N., "Human Capital and the Rise and Fall of Families", Journal of Labor Economics, 4(3), 1986, pp: 1-39.

BERNAL, R., “The Effect of Maternal Employment and Child Care on Children's Cognitive Development”, International Economic Review, 49 (4), 2008, pp: 1173-1209.

BJÖRKLUND, A. and Chadwick, L., "Intergenerational Income Mobility in Permanent and Separated Families”, Economics Letters, 80(2), 2003, pp: 239-246.

BLOOME, D., "Family Structure, Race and Intergenerational Income Mobility in the United States", Unpublished Manuscript, University of Michigan, 2014.

BURTLESS, G., "Effects of Growing Wage Disparities and Changing Family Composition on the US Income Distribution", European Economic Review, 43(4), 1999, pp: 853-865.

CAMERON, S. V. and Heckman, J., “The Dynamics of Educational Attainment for Black, Hispanic, and White Males", Journal of Political Economy, 109(3), 2001, pp: 455-499.

CARNEIRO, P., Heckman, J., and Masterov, D. V., "Labor Market Discrimination and Racial Differences in Premarket Factors", Journal of Law and Economics 48(1), 2005.

CUNHA, F., and Heckman, J., "The Technology of Skill Formation”, American Economic Review, 97 (2), 2007, pp: 31-47.

CUNHA, F., and Heckman, J., "Formulating, Identifying and Estimating the Technology of Cognitive and Noncognitive Skill Formation”, Journal of Human Resources, 43(4), 2008, pp: 738-782.

CUNHA, F., and Heckman, J., “The Economics and Psychology of Inequality and Human Development", Journal of the European Economic Association, 7(2-3), 2009, pp: 320-364.

CUNHA, F., Heckman, J., Lochner, L. and Masterov, D., "Interpreting the Evidence on Life Cycle Skill Formation", In E. A. Hanushek, \& F. Welch (Eds.), Handbook of the Economics of Education, Chap. 12. Amsterdam: North-Holland, 2008, pp. 697-812.

COUCH, K. A., and Lillard, D. R., "Divorce, Educational Attainment, and the Earnings Mobility Of Sons", Journal of Family and Economic Issues, 18(3), 1997, pp: 231-245.

DATCHER-LOURY, L., "Effects of Mother's Home Time on Children's Schooling”, The Review of Economics and Statistics, 70(3), 1988, pp: 367-373.

DEL BOCA, D., Flinn, C. and Wiswall, M., "Household Choices and Child Development", The Review of Economic Studies, 81(1), 2014, pp: 137-185.

ELLWOOD, D. T., and Jencks C., "The Uneven Spread Of Single-Parent Families: What Do We Know? Where Do We Look For Answers?", Social inequality, 1, 2004, pp: 3-77.

FRYER, R., "Racial Inequality in the 21st Century: The Declining Significance Of Discrimination", in Handbook of Labor Economics, Vol. 4, 2011, pp: 855-971.

GAYLE, G-L., Golan, L. and Soytas, M. A., "What Accounts for the Racial Gap in Time Allocation and Intergenerational Transmission of Human Capital?", Unpublished manuscript, Washington University in St. Louis, Department of Economics, 2014a.

GAYLE, G-L., Golan, L. and Soytas, M. A., "Family Structure and Intergenerational Income Mobility", Unpublished manuscript, Washington University in St. Louis, Department of Economics, $2014 b$.

GURYAN, J., Hurst E., and Kearney, M., "Parental Education and Parental Time with Children”, Journal of Economic Perspectives, 22(3), 2008, pp: 23-46.

HECKMAN, J., "Schools, Skills and Synapses”, Economic Inquiry, 46(3), 2008, pp: 289--324.

HECKMAN, J., Moon, S. H., Pinto, R., Savelyev, P. and Yavitz A., "Analyzing Social Experiments as Implemented: A Reexamination of the Evidence From the HighScope Perry Preschool Program", Quantitative Economics, 1(1), 2010a, pp: 1-46. 
HECKMAN, J., Moon, S. H., Pinto, R., Savelyev, P. and Yavitz A., “The Rate Of Return to the Highscope Perry Preschool Program”, Journal of Public Economics, 94, 2010b, pp: 114-128.

HECKMAN, J., Pinto, R. and Savelyev, P., "Understanding the Mechanisms through Which an Influential Early Childhood Program Boosted Adult Outcomes”, American Economic Review, 103(6), 2013, pp: 2052-86.

HECKMAN, J., and Mosso, S., "The Economics of Human Development and Social Mobility", Annual Review of Economics, 6, 2014, pp: 689-733.

HILL, M. S., Russell, C. and Stafford, F. P., "Allocation of time to preschool children and educational opportunity", Journal of Human Resources, 9(3), 1074, pp: 323-341.

HILL, M. S., Russell, C. and Stafford, F. P., "Parental Care of Children: Time Diary Estimates of Quantity, Predictability, and Variety", The Journal of Human Resources, 15(2), 1980, pp: 219-239.

HILL, M. S., “The wage effects of marital status and children”, Journal of Human Resources, 14(4), 1979, pp: 579-594.

HUGGETT, M., Ventura, G. and Yaron A., "Sources of Lifetime Inequality", American Economic Review, 101(7), 2011, pp: 2923-54.

KEANE, M. P. and Wolpin, K. I., “The career decisions of young men”, Journal of Political Economy, 105(3), 1997, pp: 473-522.

LEE, S. Y. and Seshadri, A., "On the intergenerational transmission of economic status", Unpublished manuscript, University of Wisconsin--Madison, Department of Economics, 2014.

LEIBOWITZ, A., "Parental inputs and children's achievement", The Journal of Human Resources, 12(2), 1977, pp: 242-251.

MCLANAHAN, S. and Percheski, C., "Family structure and the reproduction of inequalities", Annual. Review of Sociololgy, 34, 2008, pp: 257-276.

MARTIN, M. A., "Family structure and income inequality in families with children, 1976 to 2000", Demography, 43(3), 2006, pp: 421-445.

MARTIN, M. A., "Family Structure and the Intergenerational Transmission of Educational Advantage", Social Science Research, 41(1), 2012, pp: 33-47.

MCLANAHAN, S., "Diverging Destinies: How Children Are Faring Under the Second Demographic Transition", Demography, 41(4), 2004, pp: 607-627.

RIOS-RULL, J-V. and Sanchez-Marcos, V., "College Attainment of Women", Review of Economic Dynamics, 5(4), 2002, pp: 965-998.

ROMER, P., "Human capital and growth: Theory and evidence", Carnegie-Rochester Conference Series on Public Policy, Elsevier, 32(1), 1990, pp: 251-286. 


\section{Appendix}

The equations in Table 3.1 are estimated as a system 3SLS and the standard errors are reported in the parentheses. In the estımation shown in Table A.1 FLInc (MLInc) is the total labor income of the father (mother) in the first 5 years of the child's life. HSH is equal tol if the child has more than a high school education and equals 0 otherwise. SC is equal to 1 if the child has more than some college education, and equals 0 otherwise. COL is equal to 1 if the child graduated from college and equals 0 otherwise. FTime (MTime) is total time investment of the father (mother) in the first 5 years of the child's life (sum of discrete variables which take the values $0,1,2$ ). MWhours (FWhours) is the total work hours of the mother (father) in the first 5 years of the child's life (sum of discrete variables which take the values $0,1,2$ ).

Table A.I: Three-stage Least Squares Estimation: All Outcomes

\begin{tabular}{|c|c|c|c|c|c|c|c|c|c|}
\hline VARIABLES & $\begin{array}{c}(1) \\
\text { FLInc }\end{array}$ & $\begin{array}{c}(2) \\
\text { MLInc }\end{array}$ & $\begin{array}{c}(3) \\
\text { HSH }\end{array}$ & $\begin{array}{l}\text { (4) } \\
\text { SC }\end{array}$ & $\begin{array}{c}(5) \\
\mathrm{COL} \\
\end{array}$ & $\begin{array}{c}(6) \\
\text { MTime } \\
\end{array}$ & $\begin{array}{c}(7) \\
\text { FTime }\end{array}$ & $\begin{array}{c}(8) \\
\text { MWHours }\end{array}$ & $\begin{array}{c}\text { (9) } \\
\text { FWHours }\end{array}$ \\
\hline \multirow[t]{2}{*}{ F.W.Hours } & 8.287 & & & & & 0.116 & 0.244 & 0.038 & \\
\hline & $(0.755)$ & & & & & $(0.207)$ & $(0.269)$ & $(0.372)$ & \\
\hline \multirow[t]{2}{*}{ F. HS } & -97.1 & & 0.063 & 0.003 & -0.002 & 0.319 & 0.016 & 0.604 & -0.894 \\
\hline & $(98.5)$ & & $(0.032)$ & $(0.052)$ & $(0.043)$ & $(0.226)$ & $(0.298)$ & $(0.581)$ & (13.15) \\
\hline \multirow[t]{2}{*}{ F. SC } & -134 & & 0.055 & 0.132 & 0.055 & 0.045 & -0.225 & -0.044 & 13.38 \\
\hline & (106) & & $(0.023)$ & $(0.038)$ & $(0.031)$ & $(0.157)$ & $(0.201)$ & $(0.289)$ & (14.10) \\
\hline \multirow[t]{2}{*}{ F. COL } & 296 & & -0.044 & 0.008 & 0.120 & -0.155 & 1.048 & -1.125 & -24.49 \\
\hline & (139) & & $(0.032)$ & $(0.051)$ & $(0.042)$ & $(0.243)$ & $(0.267)$ & $(0.324)$ & (19.88) \\
\hline \multirow[t]{2}{*}{ F. Age 5} & -4.922 & & & & & & & & 0.682 \\
\hline & $(6.646)$ & & & & & & & & $(0.894)$ \\
\hline \multirow[t]{2}{*}{ F. Age $5 \mathrm{Sq}$. } & 0.134 & & & & & & & & -0.017 \\
\hline & $(0.185)$ & & & & & & & & $(0.025)$ \\
\hline \multirow[t]{2}{*}{ F. Age 5 Cube } & -0.001 & & & & & & & & 0.001 \\
\hline & $(0.002)$ & & & & & & & & $(0.001)$ \\
\hline \multirow[t]{2}{*}{ F. Age $5 \times$ F. HS } & 7.519 & & & & & & & & 0.241 \\
\hline & (8.549) & & & & & & & & $(1.139)$ \\
\hline \multirow[t]{2}{*}{ F. Age $5 \times$ F. SC } & 12.170 & & & & & & & & -1.233 \\
\hline & $(9.410)$ & & & & & & & & (1.249) \\
\hline \multirow[t]{2}{*}{ F. Age $5 \times$ F. COL } & -28.09 & & & & & & & & 2.031 \\
\hline & (12.04) & & & & & & & & $(1.712)$ \\
\hline \multirow[t]{2}{*}{ F. Age $5 \times$ F. HS Sq. } & -0.180 & & & & & & & & -0.012 \\
\hline & $(0.242)$ & & & & & & & & $(0.032)$ \\
\hline \multirow[t]{2}{*}{ F. Age $5 \times$ F. SC Sq. } & -0.350 & & & & & & & & 0.037 \\
\hline & $(0.272)$ & & & & & & & & $(0.036)$ \\
\hline
\end{tabular}


Table A. I : (Contd.) Three-stage Least Squares Estimation: All Outcomes

\begin{tabular}{|c|c|c|c|c|c|c|c|c|c|}
\hline VARIABLES & $\begin{array}{c}(1) \\
\text { FLInc }\end{array}$ & $\begin{array}{c}(2) \\
\text { MLIne }\end{array}$ & $\begin{array}{c}(3) \\
\text { HSH }\end{array}$ & $\begin{array}{l}\text { (4) } \\
\text { SC }\end{array}$ & $\begin{array}{c}(5) \\
\text { COL }\end{array}$ & $\begin{array}{c}(6) \\
\text { MTime }\end{array}$ & $\begin{array}{c}(7) \\
\text { FTime }\end{array}$ & $\begin{array}{c}\text { (8) } \\
\text { MW Hours }\end{array}$ & $\begin{array}{c}(9) \\
\text { FW Hours }\end{array}$ \\
\hline \multirow[t]{2}{*}{ F. Age $5 \times$ F. COL Sq. } & 0.855 & & & & & & & & -0.055 \\
\hline & $(0.341)$ & & & & & & & & $(0.048)$ \\
\hline \multirow[t]{2}{*}{ F. Age $5 \times$ F. HS Cube } & 0.001 & & & & & & & & 0.0012 \\
\hline & $(0.002)$ & & & & & & & & $(0.001)$ \\
\hline \multirow[t]{2}{*}{ F. Age $5 \times$ F. SC Cube } & 0.003 & & & & & & & & -0.0014 \\
\hline & $(0.003)$ & & & & & & & & $(0.001)$ \\
\hline \multirow[t]{2}{*}{ F. Age $5 \times$ F. COL Cube. } & -0.008 & & & & & & & & 0.001 \\
\hline & $(0.003)$ & & & & & & & & $(0.001)$ \\
\hline \multirow[t]{2}{*}{ MWHours } & & 1.331 & & & & -0.339 & 0.522 & & -0.003 \\
\hline & & $(0.075)$ & & & & $(0.110)$ & $(0.126)$ & & $(0.041)$ \\
\hline \multirow[t]{2}{*}{ M. HS } & & -29.53 & 0.089 & 0.081 & -0.019 & 0.921 & -0.328 & -7.282 & 0.059 \\
\hline & & $(37.67)$ & $(0.040)$ & $(0.065)$ & $(0.052)$ & $(0.278)$ & $(0.389)$ & $(33.765)$ & $(0.219)$ \\
\hline \multirow[t]{2}{*}{ M. SC } & & 44.86 & 0.007 & -0.041 & 0.017 & 0.942 & 0.270 & 2.930 & 0.207 \\
\hline & & $(39.80)$ & $(0.030)$ & $(0.049)$ & $(0.039)$ & $(0.168)$ & $(0.273)$ & (34.794) & $(0.136)$ \\
\hline \multirow[t]{2}{*}{ M. COL } & & -46.14 & 0.083 & 0.120 & 0.040 & 0.133 & -0.693 & 11.450 & 0.247 \\
\hline & & $(57.96)$ & $(0.036)$ & $(0.057)$ & $(0.047)$ & $(0.218)$ & $(0.263)$ & $(53.920)$ & $(0.154)$ \\
\hline \multirow[t]{2}{*}{ M. Age 5} & & -1.315 & & & & & & 1.082 & \\
\hline & & $(3.068)$ & & & & & & $(2.721)$ & \\
\hline \multirow[t]{2}{*}{ M. Age $5 \mathrm{Sq}$. } & & 0.031 & & & & & & -0.021 & \\
\hline & & $(0.093)$ & & & & & & $(0.083)$ & \\
\hline \multirow[t]{2}{*}{ M. Age 5 Cube } & & -0.001 & & & & & & 0.001 & \\
\hline & & $(0.001)$ & & & & & & $(0.002)$ & \\
\hline \multirow[t]{2}{*}{ M. Age $5 \times$ M. HS } & & 2.137 & & & & & & 1.062 & \\
\hline & & (3.547) & & & & & & (3.191) & \\
\hline \multirow[t]{2}{*}{ M. Age $5 \times$ M. SC } & & -4.125 & & & & & & -0.545 & \\
\hline & & $(3.820)$ & & & & & & (3.344) & \\
\hline \multirow[t]{2}{*}{ M. Age $5 \times$ M. COL } & & 3.474 & & & & & & -0.304 & \\
\hline & & $(5.448)$ & & & & & & $(5.100)$ & \\
\hline \multirow[t]{2}{*}{ M. Age $5 \times$ M. HS Sq. } & & -0.046 & & & & & & -0.039 & \\
\hline & & $(0.109)$ & & & & & & $(0.098)$ & \\
\hline \multirow[t]{2}{*}{ M. Age $5 \times$ M. SC Sq. } & & 0.122 & & & & & & 0.027 & \\
\hline & & $(0.121)$ & & & & & & $(0.106)$ & \\
\hline \multirow[t]{2}{*}{ M. Age $5 \times$ M. COL Sq. } & & -0.080 & & & & & & -0.013 & \\
\hline & & $(0.169)$ & & & & & & $(0.159)$ & \\
\hline \multirow[t]{2}{*}{ M. Age $5 \times$ M. HS Cube } & & 0.001 & & & & & & 0.001 & \\
\hline & & $(0.001)$ & & & & & & $(0.001)$ & \\
\hline \multirow[t]{2}{*}{ M. Age $5 \times$ M. SC Cube } & & -0.001 & & & & & & -0.001 & \\
\hline & & $(0.001)$ & & & & & & $(0.001)$ & \\
\hline
\end{tabular}

F. HS (M. HS) is equal to 1 if father (mother) of the child is at least a high graduate, and is equal to 0 otherwise. F. SC (M. SC) is equal to 1 if father (mother) of the child has at least some college education, and is equal to 0 otherwise. F. COL (M. COL) is equal to 1 if father (mother) of the child is a college graduate and is equal to 0 otherwise. F. Age 5 (M. Age 5) is the age of the father (mother) when the child was 5 years old. Female is equal to 1 if the child is a female and is equal to 0 otherwise). Black is equal to 1 if the child is black, and is equal to 0 otherwise. Siblings $<3$ is the number of siblings who are less 3 years of age when the child was less than 6 years old. $3>$ Siblings $\leq 6$ is the number of siblings who are between the ages of 3 and 6 when the child was less than 6 years of age. 
Table A. I: (Contd.) Three-stage Least Squares Estimation: All Outcomes

\begin{tabular}{|c|c|c|c|c|c|c|c|c|c|}
\hline VARIABLES & $\begin{array}{c}(1) \\
\text { FLInc } \\
\end{array}$ & $\begin{array}{c}(2) \\
\text { MLInc } \\
\end{array}$ & $\begin{array}{c}(3) \\
\text { HSH } \\
\end{array}$ & $\begin{array}{l}\text { (4) } \\
\mathrm{SC} \\
\end{array}$ & $\begin{array}{c}(5) \\
\text { COL } \\
\end{array}$ & $\begin{array}{c}(6) \\
\text { MTime } \\
\end{array}$ & $\begin{array}{c}(7) \\
\text { FTime }\end{array}$ & $\begin{array}{c}(8) \\
\text { MWHours } \\
\end{array}$ & $\begin{array}{c}\text { (9) } \\
\text { FWHours } \\
\end{array}$ \\
\hline \multirow[t]{2}{*}{ M. Age $5 \times$ M. COL Cube } & & 0.001 & & & & & & 0.001 & \\
\hline & & $(0.002)$ & & & & & & $(0.002)$ & \\
\hline \multirow[t]{2}{*}{ MT ime } & & & -0.014 & 0.080 & 0.069 & & 0.068 & -1.030 & \\
\hline & & & $(0.0210$ & $(0.035)$ & $(0.027)$ & & $(0.197)$ & $(0.153)$ & \\
\hline \multirow[t]{2}{*}{ FTime } & & & 0.031 & 0.100 & 0.027 & -0.009 & & & -0.063 \\
\hline & & & $(0.019)$ & $(0.029)$ & $(0.025)$ & $(0.134)$ & & & $(0.095)$ \\
\hline \multirow[t]{2}{*}{ MLInc } & & & -0.025 & -0.013 & 0.005 & & & & \\
\hline & & & $(0.009)$ & $(0.014)$ & $(0.011)$ & & & & \\
\hline \multirow[t]{2}{*}{ F LInc } & & & 0.001 & 0.001 & 0.002 & & & & \\
\hline & & & $(0.003)$ & $(0.004)$ & $(0.003)$ & & & & \\
\hline \multirow[t]{2}{*}{ Female } & & & -0.002 & 0.135 & 0.085 & 0.022 & -0.034 & & \\
\hline & & & $(0.017)$ & $(0.028)$ & $(0.022)$ & $(0.107)$ & $(0.150)$ & & \\
\hline \multirow[t]{2}{*}{ Black } & & & 0.020 & 0.082 & 0.043 & -0.726 & 0.111 & 0.326 & -0.470 \\
\hline & & & $(0.039)$ & $(0.063)$ & $(0.051)$ & $(0.206)$ & $(0.328)$ & $(0.347)$ & $(0.114)$ \\
\hline \multirow[t]{2}{*}{ Siblings $<3$} & & & -0.014 & -0.107 & -0.043 & 0.434 & 0.176 & & \\
\hline & & & $(0.017)$ & $(0.027)$ & $(0.022)$ & $(0.089)$ & $(0.163)$ & & \\
\hline \multirow[t]{2}{*}{$3>$ Siblings $\leq 6$} & & & -0.029 & -0.047 & -0.012 & 0.004 & 0.307 & & \\
\hline & & & $(0.019)$ & $(0.030)$ & $(0.025)$ & $(0.132)$ & $(0.169)$ & & \\
\hline \multirow[t]{2}{*}{ NHSFM } & & & & & & & & 0.267 & 0.280 \\
\hline & & & & & & & & $(0.652)$ & $(0.296)$ \\
\hline \multirow[t]{2}{*}{ NSCFM } & & & & & & & & 0.199 & -0.283 \\
\hline & & & & & & & & $(0.414)$ & $(0.161)$ \\
\hline \multirow[t]{2}{*}{ NCOLFM } & & & & & & & & 0.373 & 0.083 \\
\hline & & & & & & & & $(0.455)$ & $(0.193)$ \\
\hline \multirow[t]{2}{*}{ Constant } & -10.11 & 14.95 & 0.855 & -0.231 & -0.359 & 4.199 & -2.678 & -8.298 & 1.089 \\
\hline & $(77.65)$ & (32.66) & $(0.108)$ & $(0.172)$ & $(0.140)$ & $(2.076)$ & $(2.724)$ & $(28.60)$ & (10.43) \\
\hline $\mathrm{N}$ & 1,335 & 1,335 & 1,335 & 1,335 & 1,335 & 1,335 & 1,335 & 1,335 & 1,335 \\
\hline
\end{tabular}


